\title{
Administrative Sanctions for Hospitals Which Grant Permission for Forced Taking the Corpse of Suspect Covid-19 Patients
}

\begin{abstract}
Asmuni
Faculty of Law, Hang Tuah University, Surabaya

This study is intended to analyze the bodies of suspect Covid-19 patients in the Covid-19 Protocol and the responsibilities of the perpetrators of forcibly taking the bodies of Suspect or Probable patients in criminal law. This research is a juridical normative research, which is focused on studying the application of norms in positive law by combining legal materials which are secondary and primary legal materials. The approach taken is a statue and a conceptual approach. Based on the results of this study it can be concluded that the patient's body is a suspect Covid-19 body, it must be treated like the Covid-19 body until there is a result from the swab test to fulfill the rights of the body, the responsibility of the perpetrator of forced taking of the suspect / probable patient's body in criminal law, among others sentenced to a criminal sentence on the basis of Article 5 of Law No. 4 of 1984 concerning Outbreaks of Infectious Diseases with the threat of one year in prison or a fine of up to Rp. 100,000,000 (One Hundred Million Rupiah).
\end{abstract}

Keywords: administrative sanctions, forced collection of bodies, covid-19 corpses

\section{Introduction}

On December 31, 2019, the World Health Organization China Office reported a case of pneumonia of unknown etiology in Wuhan City, Hubei Province, China $^{1}$. Corona viruses are large number of viruses that cause illnesses ranging from mild to severe symptoms. There are at least two types of corona virus that are known to cause diseases that can cause severe symptoms such as Middle East Respiratory Syndrome (MERS) and Severe Acute Respiratory Syndrome (SARS). ${ }^{2}$ Based on Republic of Indonesia Law Number 4 of 1984 concerning infectious disease outbreaks, an outbreak is an outbreak of an infectious disease in a community where the number of sufferers has increased significantly more than usual conditions at certain times and areas and can cause disasters and based on the Indonesian Dictionary, A pandemic is an outbreak that occurs simultaneously everywhere, covering a large geographical area. Not all people understand the transmission of Covid-19 from one person to another correctly. Touching the body or have close contact with the body of a Suspect Covid-19 patient is not exactly infected us. Excessive concern often leads people to isolate families from Suspect Covid-19 patients. This phenomenon causes the process of covering Covid-19 patients often doubt that the corpses of Covid-19 patients are in accordance with religious law or not. The removal of the Suspect Covid-19 corpse by the family will endanger the people who carry out the corpse. There is still the Covid-19 virus attached to the body, which is basically the same in all other infectious diseases efforts to forcibly take the bodies of suspected Covid-19 taking the bodies of suspected Covid-19 will increase the risk of Covid-19 transmission to the family. There have been so many cases of forcibly taking the bodies of Suspect Covid-19 patients that have occurred in Indonesia, but there has not been a single legal action taken by law enforcement officials to take action against and detain the perpetrators of forcibly taking the bodies of Suspect/ Probable Covid-19 patients. This causes the absence of legal certainty, whether it is legal protection for the hospital or for the patient's own family. Forced retrieval of the corpse of the corona virus or Covid-19 is considered dangerous. Because the disease that 
is being faced by the whole world is a disease that is easily transmitted. In practice, it often turns out that the bodies of Covid-19 patients are forcibly taken. The perpetrators of taking the bodies are usually more than one person involved in the incident of taking the bodies. The perpetrators consisted or several other people who participated.

Moeljanto said that the definition of a criminal act is an act that is prohibited by a prohibition law which is accompanied by a threat (sanction) in the form of a certain crime, for those who violate the prohibition. In the concept of the Criminal Code, a criminal act is defined as an act of taking or not doing something which is stated by statutory regulations as a prohibited act and is punishable by crime. ${ }^{3}$ Hospital is a public service organization that has responsibility for every public health service it provides. This responsibility is to provide quality, affordable health services based on the principles of being safe, comprehensive, nondiscriminatory, participatory and providing protection for the community as health service users (health receivers), as well as for health service providers in order to realize the highest health status. Based on the above case, the researcher wants to study and analyze more deeply the Criminal Law Aspects of forcibly taking the bodies of Suspect / Probable Covid-19 patients at the Hospital and the responsibility of the perpetrators of forcibly taking the bodies of Suspect / Probable Covid-19 patients in Criminal Law.

\section{Research Method}

This research is a normative juridical legal research. Based on the consideration that this research is in problem analysis is carried out by combining legal materials which are secondary to primary obtained in the field. The approach used is a statutory approach (statute approach) and a conceptual approach. The legal materials that have been obtained are then analyzed by describing the results of research based on information from a situation or event that is the object of systematic discussion through materials. Legal materials that have been collected according to the needs of the research being analyzed

\section{Results and Discussion}

A. Responsibilities of the Perpetrators of Forced Retrieval of the bodies of Suspect Patients in Criminal Law.

Criminal Liability Criminal action is an act that is prohibited by a legal rule where it is accompanied by a threat (sanction) in the form of a certain crime, for whoever violates the prohibition. Moeljanto also said with the same substance that a criminal act is an act which is prohibited and punishable by punishment, whoever violates the prohibition. When it is said that a criminal act is an act which is prohibited and threatened with punishment, then the elements of a criminal act include several things. ${ }^{4}$ First, the act takes the form of an active or passive behavior which results in the emergence of a thing or condition that is prohibited by law. Second, the behavior and consequences that arise must be against the law in both a formal and material sense. Third, there are certain things that accompany the resulting behavior which is prohibited by law to prevent criminal acts from being committed by upholding legal norms for the protection of the community, resolving conflicts caused by criminal acts, restoring balance, bringing about a sense of peace in society; to socialize the convicted convict by providing guidance so that he becomes a good person and freeing the guilt of the convict, criminal liability is applied by using punishment. ${ }^{5}$ Criminal responsibility must take into account that criminal law must be used to create a just and prosperous society with material and spiritual equality. The criminal law is used to prevent or overcome unwanted acts in the criminal law system in Indonesia. To determine whether an act is a criminal act or not is to see whether there is a provision that the act is a criminal act. This relates to the validity of the legality principle stipulated in Article 1 paragraph (1) of the Criminal Code which reads "no act can be punished except for the strength of the criminal rules that exist in the laws and regulations that existed before the act was 
committed". ${ }^{5}$ Even though a person who has committed a criminal act and has fulfilled the elements of a criminal act, it is not certain that the person has committed a criminal act, because it still requires an element of guilt in order to be liable for criminal responsibility for the act, namely: 6

\section{The ability to be responsible;}

2. There was an error in the form of intentional or negligent;

\section{Absence of excuses.}

Discussing criminal liability must inevitably be preceded by an explanation of the criminal act. This is because a person cannot be held responsible for a crime without first committing a criminal act. Criminal liability as the continuation of an objective reproaches that is in a criminal act and subjectively there is a qualification to be convicted for that act. The basis for the existence of a criminal act is the principle of legality, while the basis for the conviction of the maker is the principle of guilt. This means that the perpetrator of a criminal act will only be punished if he or she has committed the criminal act. Without mistakes, there will never be any criminal responsibility. So it is known the principle of "no crime without error" 7 (geen straf zonder schuld). This principle of error is a fundamental principle in criminal law. Mistakes are condemned by the perpetrator of the crime because from the perspective of society, he can actually do something else if he does not want to commit the act. The principle of error (principle of culpability), which is based on a monodualistic balance, that the principle of error is based on a monodualistic balance that the principle of error based on the value of justice must be aligned in pairs with the principle of legality based on the value of certainty. Although the concept is based on the principle that criminal responsibility is based on error, in some cases it does not rule out vicarious liability and strict liability. Strict liability is defined as a criminal act by not requiring the perpetrator to be guilty of one or more of the actus reus. Strict liability is a liability without fault, in which case the perpetrator of a criminal offense can already be convicted if he has committed an act that is prohibited as defined in the law without looking further into the inner attitude of the perpetrator. ${ }^{8}$ Vicarius liability is legal liability for someone else's wrongdoing. The two people must have a relationship, namely a superior and subordinate relationship or an employer and labor relationship or an employment relationship. In short, this accountability is called substitute liability. Forced collection of the bodies of suspicious / probable patients is to take the bodies of suspect covid-19 patients by force and not in accordance with special procedures or protocols for monitoring the bodies of suspected / probable covid-19. The perpetrator of the forced taking of the corpse, the probable covid-19 body, has been subject to sanctions in several regulations.

The word force means to do something that is required even though it does not want to, while the meaning of the word take is to hold it and then carry it, lift it, and so on. ${ }^{9}$ What is meant by forcing is putting pressure on a person so that that person does something against his own will. Forcing other people to hand over their own things is also extortion. Meanwhile, what is meant by against the rights is against the law, not entitled or contrary to the law. The thing that underlies criminal responsibility is the understanding that every human being is gifted by God Almighty has a mind and conscience which gives him the ability to distinguish between good and bad which will guide and direct attitudes and behavior in living his life. With this intellect and conscience, humans have the freedom to decide their own behavior or actions. In addition to balancing freedom, humans have the ability to be responsible for all the actions they do. One of the regulations that have been made is the Jakarta Regional Regulation regarding Corona. This regulation covers a broad range of issues ranging from the regulation of the rights and obligations and responsibilities of the government to the implementation of Large-Scale Social Restrictions (PSBB). Meanwhile, imprisonment sanctions for violators of the Jakarta Corona Jakarta Regional Regulation have been removed and replaced with fines such as fines for forcibly taking the body of 
Covid-19.

Based on Article 31 Paragraph (1) of the district regulations, the act of forcibly taking the body of Covid-19 is also classified as a criminal act. However, if the collection of Covid-19's body is accompanied by threats, the value of the fine will increase to IDR 7.5 million. ${ }^{10}$ The Police of the Republic of Indonesia have stated that the forcible collection of bodies that have tested positive for Covid-19 is an act of violating applicable laws and regulations because it will cause harm to various parties and this is also a criminal act. Many parties have become suspects by the Indonesian National Police. The Police of the Republic of Indonesia have also compiled regulations or instructions to resolve cases of forcibly taking the bodies of Covid-19 patients, namely by issuing a telegram letter from the Chief of Police Number ST / 1618 / VI / Ops. 2 / 2020 Firm action is needed against those who are still forcibly taking the bodies of Covid-19 patients. $^{11}$ So it also requires the involvement of religious leaders, the community, humanists, and sociologists, anthropologists, to communicate and provide understanding to the community so that there should be no more cases of forced taking of Covid-19's body.

B. Criminal Sanctions for Perpetrators of Forced Retrieval of the Body of a Suspect Covid-19 Patient

The law must not be late with the development of society because if it is ignored, it will be difficult to hold criminal perpetrator criminally. ${ }^{12}$ Criminal law policies must be carried out in an integrated manner in law enforcement. Forcibly taking the bodies of Covid-19 patients by parties who do not have the authority is an act against the law. This is contrary to the procedures for handling the body of Covid-19. According to the Indonesian Criminal Code system, what can be the subject of criminal law is a person or a human being. This can be seen in each article in the Criminal Code Book II and Book III. Most of the rules of criminal law begin with the word whoever is the translation word for the word Dutch. In fact, forcibly taking the corpse of the Corona or Covid-19 Virus is considered dangerous. Due to the disease that is being faced by the whole world, it is a highly contagious disease. In practice, it turns out that there is often the forcible taking of the bodies of Covid-19 patients. The perpetrators are those who carry out the action, usually more than one person involved in the taking of the body.

The perpetrators consisted of one or several other people who participated. The implementation of criminal law against the perpetrators of forcibly taking the bodies of Covid-19 patients related to the accountability of the perpetrators means wearing the disgraceful nature of the criminal act against that person in accordance with the role and capacity of the perpetrator or his contribution in realizing a criminal act, so it deserves to be inflicted with sorrow. Thus, the benchmarks or determination of the scope of criminal liability are highly dependent on the formulation and scope of the predetermined criminal offense as well as the concept of the Inclusion Doctrine in positive criminal law. The phenomenon of the bodies of Suspect patients related to the Covid-19 corona virus being forcibly taken away by family members often occurs in Indonesia. If this is allowed, it will be difficult to hold the criminal perpetrators accountable. Law enforcement in handling Covid-19 must be carried out in a comprehensive manner while still observing a person's ability to carry out criminal responsibility. Liability for criminal acts is only carried out by the perpetrator of the criminal act based on the principle applicable in the Criminal Law, namely "Nullu Poena Sine Crimen" (no crime without a criminal act), this principle can be understood that to be charged a person with a legal responsibility must have committed the act. Criminal Liability can be held to persons or legal entities in criminal law. Criminal liability contains the principle of error (principle of culpability), which is based on a monodualistic balance that states that the principle of error based on the value of justice must be aligned with the principle of legality which is based on the value of certainty. Although the concept is based on the principle that criminal liability is based on error, in some cases it is not. 
The Police of the Republic of Indonesia have also stated that if there are parties who forcibly take the bodies of Covid-19 patients, it is not according to the applicable procedure, because it will endanger many parties and this is a criminal act. In fact, many parties have been made suspects by the Indonesian National Police. The Police of the Republic of Indonesia have also issued regulations or instructions to resolve cases of forcibly taking the bodies of Covid-19 patients, namely by issuing a telegram letter from the National Police Chief Number ST / 1618 / VI / Ops.2 / 2020. Firm action is needed against those who are still forcibly taking the bodies of Covid19 patients. So it also requires the involvement of religious figures, society, humanists, sociologists, anthropologists, to communicate as well as providing understanding to the public so that there should not be another case of forcibly taking the body of Covid-19. ${ }^{13}$

In fact, quite a number of parties have been named as suspects in the case. One of the reasons for the determination of the suspect by the police is to prevent the recurrence of cases of forcibly taking the bodies of Covid-19 patients by the family. ${ }^{14}$

According to Sholehuddin, the objectives of criminal sanctions were: ${ }^{15}$

1. To provide a deterrence and deterrence effect. Determination here means keeping the criminal offender from repeating the same crime. Determination aims to remind and frighten potential criminals in society from committing crimes.

2. To provide rehabilitation. Criminalization is a way to achieve reform or rehabilitation of criminal offenders. Criminalization is a social and moral treatment process for a convicted person to reintegrate into society properly.

3. Criminalization is carried out as a vehicle for moral education, or as a reformation process. Therefore, in the criminal process, the criminal offender is assisted to recognize and admit the wrongdoing he has been accused of.
With the Head of Police's telegram letter Number ST / 1618 / VI / Ops.2 / 2020, if there are still parties who take the corpse of a PDP Covid-19 patient by force, they may be subject to criminal sanctions. The basis is Article 5 of Law Number 4 of 1984 concerning Outbreaks of Communicable Diseases with the threat of one year in prison or a fine of up to Rp. 100,000,000 (One Hundred Million Rupiah) as regulated in Article 93 of Law Number 6 of 2018 concerning Health Quarantine. In addition, parties who forcibly take the bodies of PDP patients with Covid-19 may also be subject to layered articles, namely Article 211 of the Criminal Code in conjunction with Article 335 of the Criminal Code together with Article number 336 of the criminal code together with Article 93 of Law Number 6 of 2018, with a penalty of up to 7 (seven) years.

The special treatment of the bodies from the bathing process to the funeral, according to the authors, is part of the prevention of the spread of the corona virus. As a civil society, everyone participates in the implementation of epidemic prevention efforts. This participation is carried out by: ${ }^{16}$

1. Providing information on the presence of a patient or suspect suffering from plague;

2. Assisting in the smooth implementation of epidemic countermeasures;

3. Mobilizing community motivation in efforts to contain the epidemic;

\section{Other activities.}

If there are parties who do not heed the call for quarantine or social restrictions, then that party can be considered as not participating in the response to the Corona virus outbreak. Article 14 of Law No. 4 of 1984 has threatened that:

1. Anyone who deliberately obstructs the implementation of epidemic control as regulated in this Law, shall be punished with imprisonment of up to 1 (one) year and / or a maximum fine of Rp. 1,000,000 (one million rupiah). 
2. Anyone who due to his / her negligence obstructs the implementation of the epidemic control as regulated in this Law, shall be punished with imprisonment of up to 6 (six) months and / or a fine of up to Rp. 500,000 (five hundred thousand rupiah).

3. Criminal acts as referred to in paragraph (1) shall be crimes and criminal acts as referred to in paragraph (2) shall be violations.

It is worth noting that the actions that can be charged with criminal sanctions are contained in Article 14 paragraph (1) of Law Number 4 of 1984. In Article 5 paragraph (1) of Law Number 4 of 1984, it is stated that the efforts to overcome the epidemic include:

1. Epidemiological investigation;

2. Examination, treatment, care and isolation of patients, including quarantine measures;

3. Prevention and immunization;

4. Elimination of the cause of disease;

5. Handling of the body due to the plague;

6. Community outreach;

7. Other countermeasures.

The objectives for overcoming epidemics are regulated in the elucidation of Article 5

Paragraph (1) of Law Number 4 of 1984 concerning infectious disease outbreaks which has 2 (two) main objectives, namely:

1. Trying to reduce the death rate due to the epidemic with medication.

2. Limit the spread of disease so that sufferers do not multiply, and the epidemic does not spread to other areas.

According to researchers, if there are parties who take bodies infected with Covid-19, it is suspected that they are blocking efforts to contain the spread of the corona virus. Therefore, if based on the negligence of a party obstructs efforts to control epidemics of infectious diseases, such as the corona virus, Article 93 of Law Number 6 of 2018 concerning Health Quarantine states that: "Every person who does not comply with the implementation of Health Quarantine as referred to in Article 9 paragraph (1) and / or obstructs the implementation of Health Quarantine so as to cause a Public Health Emergency will be sentenced to imprisonment of a maximum of 1 (one) year and / or a maximum fine. Rp. 100,000,000.00 (one hundred million rupiah). "As stated in Article 212 of Law Number 8 of 1981 concerning Criminal Procedure Law, namely: "Anyone who with violence or threats of violence against a civil servant who performs his legitimate job, or against a person who while helping that civil servant because of his obligations under the law or at the request of the civil servant, is punished for resistance, with a prison sentence of -The duration is one year and four months or a maximum fine of Rp.4,500.00. “

An action prohibited by law which when violated will then result in criminal sanctions. In the legislation there are many terms used where the term has the same meaning with criminal acts, including criminal events, punishable acts, delinquency, criminal offenses, and others. The forcible taking of a corpse is against the law. Actions prohibited by law which when violated will then result in sanctions. The forced taking of the corpse of a suspect Covid-19 patient if not sanctioned not only has no deterrent effect for the perpetrator, but will also cause social impact. If the corpse of a Suspect/ Probable Covid-19 patient is not marketed in accordance with the Covi-19 protocol, it will cause the potential for Covid-19 transmission to the mourners who go to the funeral home and the person who bathed the corpse. Unbeknownst to them, the funeral and burial created a new cluster of Covid-19. The rapid and widespread spread of Covid-19 has a social impact in the form of tightening the PSBB (Large-Scale Social Restrictions) rules, so that economic activity is hampered and more and more unemployment is open. Forced retrieval of the remains of Suspect/Probable Covid-19 patients is common, one of which is for the reason that families are afraid of being considered as potential people to spread 
the Covid-19 outbreak in the neighborhood. In addition, the family of the patient's body of the suspect/probably Covid-19, if it is proven positive for Covid-19, then the funeral process will be conducted in accordance with the Covid-19 control protocol. This causes the surrounding community or neighbors to know that the patient is a Covid-19 patient. People who do not understand the information about the transmission of Covid-19 will try to refuse the burial of the body because the burial is done in the community. The public is afraid if the remains of the Covid-19 patient can transmitted the outbreak of Covid-19 in the environment even though the corpse had been marketed in accordance with the Covid-19 protocol. Obstructing officers who will conduct a formal funeral legally can indeed be punished. Law enforcement officers can use Article 178 of the Criminal Code.

Daddy Fahmanadie, a lecturer in criminal law at LambungMangkurat University, Banjarmasin, confirmed that in terms of the threat of punishment, this article may be a bit light. However, the legality of this article is an ordinary delicacy, not a delinquency of complaints. Law enforcement officers can take immediate action without anyone complaining. As for the sound of Article 178 of the Criminal Code, it is: "Whoever deliberately obstructs or obstructs the entrance or transportation of a corpse to a permitted grave threatened with imprisonment for a maximum of one month and two weeks or a maximum fine of one thousand eight hundred rupiahs ". This article is under the chapter on crimes against public order. This formula is similar in the Nederland Wetboek van Strafrecht, namely Article 148. This criminal threat is addressed to 'anyone', or anyone '. Permitted graves "This act must be done deliberately, obstructing ", meaning obstructing, so that the carriage of the corpse cannot take place (verhideren). ,Troublesome ${ }^{e e}$ means to disturb, so that although the carrying of the corpse can take place, but with difficulty (belemmeren). Carrying the body should not be prohibited which means that the carriage is appropriate, has been given permission by government officials, not burying the body in the dark. ${ }^{17}$

\section{Conclusions and Suggestions}

Conclusion From the results of the research in the previous chapter, it can be concluded below:

1. The racism of the bodies of suspected / probable Covid-19 patients in the Covid-19 protocol, namely the bodies of Covid sufferers are those infected with an infectious disease or suspected of being infected with an infectious disease and must be handled specifically, then this guideline must meet the safety requirements for medical officers and regulations Requirements' to fulfill the rights of the body. Thus, if the patient's body is a suspect / probable Covid-19 body, it must be treated like a Covid-19 body until there is a result from the swab test

2. The responsibility of the perpetrator of forcibly taking the bodies of suspected / probable patients in the criminal law includes being sentenced to criminal sanctions on the basis of Article 5 of Law Number 4 of 1984 concerning Outbreaks of Communicable Diseases with the threat of one year in prison or a fine of up to Rp. 100,000,000 (One Hundred Million Rupiah) as regulated in Article 93 of Law Number 6 of 2018 concerning Health Quarantine. In addition, parties who collect the bodies of PDP patients Covid-19 by force can also be subject to layers of articles, namely Article214KUHPjo Article335 KUHP together with Article 336 of the Criminal Code jo. Article 93 of Law Number 6 of 2018, with a penalty of up to 7 (seven) years.

\section{Suggestions}

1. The government should be more aggressive in disseminating regulations related to Covid-19 prevention, such as providing official Covid-specific regulations on the internet. If it is not broadcast officially, the public will not easily believe the information, so they ignore and don't even read the regulation. This has resulted in a lack of public knowledge regarding the regulations for dealing with Covid-19. Policymakers should be able to provide stricter regulations to take action against cases of forcibly taking the body of Covid-19 at the hospital, and it is hoped that similar cases will not occur again. 
2. It is hoped that the public will have a better understanding of the rules that apply to the Prevention of Covid-19 Transmission in Indonesia. Understand the rules that apply so that people act wisely in responding to them.

Ethical Clearance: I declare that all procedures performed this study were in accordance with the ethical standards of the institutional and/or national research committee and with the 1964 Helsinki declaration and its later amendments or comparable ethical standards

Source of Funding- Self Funding

\section{Conflict of Interest - Nil}

\section{References}

1. General Director for Controlling and Prevention of Infectious Diseases, Ministry of Health, Guidelines for the Prevention and Control of Corona Virus Disease (COVID-19), Rev04, March 2020. p. 11

2. General Director for Controlling and Prevention of Infectious Diseases, Ministry of Health, Guidelines for the Prevention and Control of Corona Virus Disease (COVID-19), Rev04, March 2020. p. 11

3. Mahrus Ali, Dasar-Dasar Hukum Pidana, Cetakan kelima, Sinar Grafika, Jakarta, 2019 page 97

4. Mahrus Ali, Dasar-Dasar Hukum Pidana, Cetakan
Medico-legal Update, October-December 2021, Vol.21, No. 4109 kelima, Sinar Grafika, Jakarta, 2019 page 78-79

5. Mahrus Ali, Dasar-Dasar Hukum Pidana, Cetakan kelima, Sinar Grafika, Jakarta, 2019 page 100

6. Mahrus Ali, Dasar-Dasar Hukum Pidana, Cetakan kelima, Sinar Grafika, Jakarta, 2019 page 100

7. M Reza Charis Kurniawan,Pertanggungjawaban Pidana Debt Collector Dalam Melakukan Pengambilan Barang Secara Paksa Terhadap Konsumen page 49

8. Mahrus Ali, Op.Cit. hal 155-157

9. No name, https://jakarta.suara.com/ $\mathrm{read} / 2020 / 10 / 19 / 191522 /$ ambil-paksa-jenazahcovid-19-siap-siap-didenda-rp-5-juta accessed on December 42020.

10. Fadhil Yazid, Penerapan Sanksi Pidana terhadap Pengambilan Paksa Jenasah Pasien Covid-19 di Indonesia, Jurnal Belo, Vol.6 No.1, 2020. page.63

11. Ubwarin, E., \& Corputty, P, Pertangungjawaban Pidana Dalam Keadaan Darurat Bencana Covid-19. Mizan: Jurnal Ilmu Hukum, Volume 9 Nomor 1, 2020, Hal 6. DOI : https://doi.org/10.32503/mizan. v9i1.1043

12. Minister of Health Circular Number HK 02.01./ Menkes/202/2020

13. R. Soesilo, Kitab Undang-Undang Hukum Pidana (KUHP) serta Komentar-Komentarnya Lengkap Pasal Demi Pasal, Politea, Bogor, 1994, hal. 149150. 